\title{
Comparison of Nitrofen Uptake via Water and Food and its Distribution in Tissue of Common Carp, Cyprinus carpio $\mathrm{L}$.
}

\author{
Yoshiyuki Inoue $\cdot$ Naoki Hashizume • \\ Erina Kikushima $\cdot$ Masanori Otsuka
}

Received: 15 February 2011/ Accepted: 21 June 2011/Published online: 30 June 2011

(C) The Author(s) 2011. This article is published with open access at Springerlink.com

\begin{abstract}
Carp (Cyprinus carpio L.) were exposed to nitrofen (NIP) by different routes (via water or food) to compare bioaccumulation parameters and tissue distribution. The bioconcentration factor of NIP was 5,100, and the lipid-corrected biomagnification factor was 0.137 . Growthcorrected elimination half lives were 2.1-3.0 days via aqueous exposure and 2.7-2.9 days via dietary exposure. From either uptake route, the tissue distribution of NIP was highest in the head, followed by muscle, viscera, dermis, digestive tract and hepatopancreas, which was highly correlated with the tissue lipid content. We conclude that the uptake route has no influence on tissue distribution of NIP and that the accumulation potential in tissues depends on the lipid content.
\end{abstract}

Keywords Nitrofen - Bioconcentration .

Biomagnification · Tissue distribution

Uptake of chemicals in biota can occur through several mechanisms and can involve the dermis, gills, pulmonary surfaces or the gut. Bioconcentration is the net accumulation in an organism of a contaminant via water only. Biomagnification is an increase in concentration from one trophic level (e.g., prey) to the next (e.g., predator) attributable to the accumulation of a contaminant via food (Newman 2009).

During the years of steep economic growth (1955-1973), Japan experienced the tragic effects of environmental

Y. Inoue $(\bowtie) \cdot N$. Hashizume $\cdot$ E. Kikushima $\cdot$ M. Otsuka Chemicals Evaluation and Research Institute, Japan,

CERI Kurume, 3-2-7 Miyanojin, Kurume-shi,

Fukuoka 839-0801, Japan

e-mail: inoue-yoshiyuki@ceri.jp pollution in the form of Minamata disease (Harada 1995), so called because it was first observed in the inhabitants of the fishing village in Minamata, Japan. This was a devastating neurological disease in humans resulting from the consumption of fish containing bioaccumulated organic mercury compounds. In the Japanese Chemical Substances Control Law (Ministry of Economy, Trade and Industry [METI] 2003), bioaccumulation of chemicals in fish is an issue of great interest. Fish muscle is considered one of the important tissues when evaluating bioaccumulation potential because fish muscle is a primary source of protein for human consumption. There is strong evidence that hydrophobic substances reach equilibrium in the lipid fraction of different tissues of an organism (Bertelsen et al. 1998; Tietge et al. 1998; Gobas et al. 1999, as cited in Arnot and Gobas 2006). However, this knowledge relies heavily on bioconcentration factor (BCF) data, and there are few experimental data that compare the tissue distribution of chemicals taken up by different routes (e.g., via water or food). Nitrofen ( $\log \mathrm{K}_{\mathrm{ow}} 4.32$, calculated by using Kowwin v. 1.68 [US Environmental Protection Agency]) is a chemical that is highly hazardous to aquatic organisms for which there is limited hazard data (Hazardous Substances Data Bank; http://www.toxnet.nlm.nih.gov). Our goal in this study was to clarify the uptake characteristics of nitrofen in carp (Cyprinus carpio L.) via water and food and to discuss its tissue distribution on the basis of lipid content.

\section{Materials and Methods}

Nitrofen (NIP; 2,4-dichloro-1-(4-nitrophenoxy) benzene) (100\%; Wako Pure Chemical Industries Ltd., Japan) was selected as a test substance for the exposure tests. Hexachlorobenzene (HCB, 99.7\%; Tokyo Chemical Industry 
Co., Ltd., Japan) was used as a reference substance for the dietary tests. Yearling carp were cultivated in our laboratory and acclimatized according to the Organization for Economic Co-operation and Development (OECD) test guideline (TG) 305 (OECD 1996). The lipid content of test fish was measured as described by Bligh and Dyer (1959). The body weights, lengths and lipid contents of test fish during the test period were $3.31-14.39 \mathrm{~g}, 6.5-10.8 \mathrm{~cm}$ and $3.52-5.59 \%$ (based on whole body wet weight), respectively (aqueous exposure) and 2.16-5.70 g, 5.7-7.6 cm and $4.57-5.84 \%$, respectively (dietary exposure).

The aqueous exposure test was carried out by the procedures of the "Flow-through Fish Test" (OECD 1996). The nominal NIP concentrations were $5.0 \mu \mathrm{g} \mathrm{L}^{-1}$ (high level) and $0.5 \mu \mathrm{g} \mathrm{L}^{-1}$ (low level). The test tank was a $70 \mathrm{~L}$ glass tank; 52 fish were used for each test. The uptake period was 60 days, and the depuration period was 7 days. Test water was kept at $25 \pm 2{ }^{\circ} \mathrm{C}$. Polyoxyethylene hydrogenated castor oil (HCO-40, Nikko Chemicals Co., Ltd., Japan) and $N, N$-dimethylformamide (DMF, Nacalai Tesque, Inc., Japan) were used to prepare the stock solution. NIP and HCO-40 (at 10 times the amount of NIP) were dissolved with DMF to prepare two concentrations of NIP stock solution: $200 \mathrm{mg} \mathrm{L}^{-1}$ for the high level and $20.0 \mathrm{mg} \mathrm{L}^{-1}$ for the low level. The stock solution for a control was set to the same HCO-40 and DMF concentrations as in the high-level NIP stock solution. The stock solution (at a flow rate of $0.04 \mathrm{~mL} \mathrm{~min}^{-1}$ ) was diluted by groundwater $\left(1,600 \mathrm{~mL} \mathrm{~min}^{-1}\right)$ from the premises of the authors' laboratory.

Test water was analyzed six times during the exposure period (after 11, 12, 26, 39, 49 and 60 days). For gas chromatography-mass spectrometry (GC-MS) analysis, NIP in test water $(20 \mathrm{~mL}$ for high level; $200 \mathrm{~mL}$ for low level) was extracted by solid-phase extraction, using a SepPak $\mathrm{C}_{18}$ (Nihon Waters K. K., Japan), and dissolved in $2 \mathrm{~mL}$ hexane (Kanto Chemical Co., Inc., Japan). Test fish were individually analyzed in two groups of two fish each, five times during the uptake period (after 12, 26, 39, 49 and 60 days) and four times during the depuration period (after 1, 4, 5 and 7 days). At the end of the exposure period, an additional five fish were taken from the low-level exposure tank and dissected into dermis (including scale, fin, and gill), head, digestive tract, hepatopancreas, viscera and muscle. Each type of tissue from the five fish was pooled into a single combined sample for tissue-specific analysis. The whole fish and main fish tissue samples were shredded using a polytron (Kinematica, Bohemia, NY, USA), and $5 \mathrm{~g}$ of each fish sample (except for dermis, digestive tract, hepatopancreas and viscera which had less than about $5 \mathrm{~g}$ ) was used for GC-MS analysis. All samples from test fish were homogenized in $15 \mathrm{~mL}$ acetonitrile. The supernatant obtained by centrifugation of the homogenized sample
$(7,000 \times g, 5 \mathrm{~min})$ was brought to a volume of $25 \mathrm{~mL}$ with acetonitrile. One milliliter of the extract was evaporated to dryness and dissolved in $10 \mathrm{~mL}$ hexane. Both test water and test fish samples were analyzed by GC-MS using an instrument (QP2010; Shimadzu Co., Japan) equipped with an HP-5MS column $(30 \mathrm{~m} \times 0.25 \mathrm{~mm}$; Agilent Technologies, Inc., Santa Clara, CA, USA). The column temperature was held at $50^{\circ} \mathrm{C}$ for $1 \mathrm{~min}$, ramped to $300^{\circ} \mathrm{C}$ at $40^{\circ} \mathrm{C} /$ $\mathrm{min}$ and then held for $3 \mathrm{~min}$. Ion monitoring was at $\mathrm{m} / \mathrm{z}=$ 202. A kinetic BCF was calculated according to OECD TG 305 as follows (parameters for BCF calculation are shown in Table 1):

$\mathrm{BCF}_{\mathrm{k}}=\mathrm{K}_{\text {uptake }} / \mathrm{K}_{\text {total }}$

where $\mathrm{BCF}_{\mathrm{k}}$ is a kinetic bioconcentration factor, $\mathrm{K}_{\text {uptake }}$ is uptake rate constants, $K_{\text {total }}$ is overall elimination rate constants.

The dietary exposure test was performed according to Anonymous $(2004 \mathrm{a}, \mathrm{b})$. The test tank was a $100 \mathrm{~L}$ glass tank; 110 test fish were used for each test. The uptake period was 10 days, and the depuration period was 15 days to obtain the elimination half-life of HCB as well as that of NIP. Other conditions were the same as for the aqueous exposure test.

The test diet was prepared as follows. NIP $(500 \mathrm{mg}$ for high level, $50.0 \mathrm{mg}$ for low level) and HCB (50.0 mg for both levels) were co-dissolved in $50 \mathrm{~mL}$ acetone (Wako Pure Chemical Industries, Ltd.) to which $50 \mathrm{~g}$ of fish feed oil (Riken feed oil omega, Eiken Shoji Co., Ltd., Japan) was added. After thoroughly mixing this solution, the solvent was removed using a rotary evaporator. Four hundred fifty grams of fish pellet feed (particle size $0.4-0.9 \mathrm{~mm}$, lipid

Table 1 Parameters used for calculation of bioconcentration factors (BCFs) for nitrofen (NIP) under high- and low-exposure conditions

\begin{tabular}{lll}
\hline Parameter & \multicolumn{2}{l}{ NIP exposure level } \\
\cline { 2 - 3 } & High & Low \\
\hline Fish $_{\text {lipid }}(\%)$ & 4.97 & 4.21 \\
$\mathrm{~K}_{\text {uptake }}\left(\mathrm{d}^{-1}\right)$ & 1,800 & 1,270 \\
$\mathrm{~K}_{\text {total }}\left(\mathrm{d}^{-1}\right)$ & 0.351 & 0.248 \\
$\mathrm{~K}_{\text {growth }}\left(\mathrm{d}^{-1}\right)$ & 0.0186 & 0.0186 \\
$\mathrm{~K}_{\text {elim }}\left(\mathrm{d}^{-1}\right)$ & 0.332 & 0.230 \\
$t_{1 / 2}(\mathrm{~d})$ & 2.1 & 3.0 \\
$\mathrm{BCF}_{\mathrm{k}}$ & 5,100 & 5,100 \\
$\mathrm{BCF}_{\mathrm{ss}}$ & 5,400 & 4,700 \\
$\mathrm{BCF}_{\mathrm{k}, \text { lipid }}$ & 5,200 & 6,100 \\
\hline
\end{tabular}

Fish $_{\text {lipid }}$, fish lipid content based on wet weight; $K_{\text {uptake, }}$ uptake rate constants; $\mathrm{K}_{\text {total }}$, overall elimination rate constants; $\mathrm{K}_{\text {growth }}$, overall growth rate constants for fish; $\mathrm{K}_{\text {elim}}$, growth-corrected elimination rate constants; $t_{1 / 2}$, growth-corrected elimination half-life; $\mathrm{BCF}_{\mathrm{k}}$, kinetic bioconcentration factor; $\mathrm{BCF}_{\mathrm{ss}}, \mathrm{BCF}$ at steady state; $\mathrm{BCF}_{\mathrm{k}}$, lipid, 5\% lipid-normalised $\mathrm{BCF}$ 
Table 2 Parameters used for calculation of biomagnification factors (BMFs) for nitrofen (NIP) and hexachlorobenzene (HCB) under high- and low-exposure conditions

\begin{tabular}{|c|c|c|c|c|}
\hline \multirow[t]{2}{*}{ Parameter } & \multicolumn{2}{|l|}{ NIP } & \multicolumn{2}{|l|}{ HCB } \\
\hline & High & Low & High & Low \\
\hline $\operatorname{Diet}_{\text {lipid }}(\%)$ & 15.5 & 15.4 & 15.5 & 15.4 \\
\hline Fish $_{\text {lipid }}(\%)$ & 5.34 & 5.34 & 5.34 & 5.34 \\
\hline $\mathrm{C}_{0, \text { fish }}\left(\mu \mathrm{g} \mathrm{g}^{-1}\right)$ & 40.1 & 4.11 & 13.8 & 13.6 \\
\hline $\mathrm{K}_{\text {total }}\left(\mathrm{d}^{-1}\right)$ & 0.286 & 0.269 & 0.0930 & 0.0846 \\
\hline $\mathrm{K}_{\text {growth }}\left(\mathrm{d}^{-1}\right)$ & 0.0278 & 0.0291 & 0.0278 & 0.0291 \\
\hline $\mathrm{K}_{\text {elim }}\left(\mathrm{d}^{-1}\right)$ & 0.258 & 0.240 & 0.0652 & 0.0555 \\
\hline$t_{1 / 2}(\mathrm{~d})$ & 2.7 & 2.9 & 10.6 & 12.5 \\
\hline Alpha $(\alpha)$ & 0.406 & 0.380 & 0.733 & 0.717 \\
\hline $\mathrm{BMF}$ & 0.0471 & 0.0476 & 0.337 & 0.388 \\
\hline Lipid factor $(\mathrm{F})$ & 0.344 & 0.347 & 0.344 & 0.347 \\
\hline $\mathrm{BMF}_{\text {lipid }}$ & 0.137 & 0.137 & 0.982 & 1.12 \\
\hline
\end{tabular}

Diet $_{\text {lipid }}$, diet lipid content based on wet weight; fish ${ }_{\text {lipid }}$, fish lipid content based on wet weight; $\mathrm{C}_{0}$, fish, concentration in fish at the beginning of depuration derived from the regression line intercept; $K_{\text {total }}$, overall elimination rate constants; $K_{\text {growth }}$, overall growth rate constants for fish; $\mathrm{K}_{\text {elim }}$, growth-corrected elimination rate constants; $t_{1 / 2}$, growth-corrected elimination half-life; alpha $(\alpha)$, calculated uptake efficiency of test

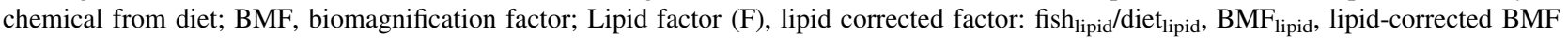

content $\geq 3 \%$; Nippon Formula Feed Manufacturing Co., Ltd., Japan) was added to the fish feed oil, mixed well and then dried under ambient conditions for about $24 \mathrm{~h}$. The control diet was treated the same as the test diet but without NIP or HCB. The nominal concentrations of test substances in the test diet were $1,000(\mathrm{NIP})+100 \mu \mathrm{g} \mathrm{g}^{-1}$ (HCB) (high level) and $100(\mathrm{NIP})+100 \mu \mathrm{g} \mathrm{g}^{-1}$ (HCB) (low level). Food was added to the tanks at a feeding rate $(I)$ of $0.03 \mathrm{~g} \mathrm{diet} / \mathrm{g}$ live fish/day and the fish were allowed to feed naturally. During the depuration period, the fish were fed the control diet. The lipid content of the test diets averaged from samples at the beginning and end of the uptake period were (mean \pm SD) $15.5 \pm 0.2 \%$ (high level), $15.4 \pm 0.2 \%$ (low level) and $15.0 \pm 0.3 \%$ (control).

For GC-MS analysis of the test diet, $1 \mathrm{~g}(\mathrm{n}=3)$ was homogenized with $15 \mathrm{~mL}$ hexane, and the supernatant obtained by centrifugation $(7,000 \times g, 5 \mathrm{~min})$ was brought to a volume of $25 \mathrm{~mL}$ with hexane. One milliliter of the hexane extract was diluted to $10 \mathrm{~mL}$ with hexane for GCMS analysis. Test fish were analyzed individually in two groups of five fish each at the end of the uptake period (after 10 days) and five times during the depuration period (after 1, 5, 7, 9 and 15 days). At the end of the exposure period (after 10 days), an additional five fish were collected from the low-level test tank and dissected as in the aqueous exposure test. For GC-MS analysis, the test fish were treated using the same method as with the aqueous exposure test but using acetone for extracting NIP and HCB. NIP and HCB in both diet and fish tissue were measured using the same GC-MS conditions as described for the aqueous exposure test. Ion monitoring for $\mathrm{HCB}$ was at $m / z=283$. BMF was calculated according to Anonymous (2004a) as follows (parameters for BMF calculation are shown in Table 2):

$$
\begin{aligned}
& \text { alpha }(\alpha)=\left(\mathrm{C}_{0, \text { fish }} \times \mathrm{K}_{\text {total }}\right) /\left(\mathrm{I} \times \mathrm{C}_{\text {diet }}\right) \\
& /\left(1-\exp \left(-\mathrm{K}_{\text {total }} \times \mathrm{t}\right)\right) \\
& \mathrm{BMF}=\mathrm{I} \times \alpha / \mathrm{K}_{\text {elim }} \\
& \mathrm{BMF}_{\text {lipid }}= \mathrm{BMF} / \mathrm{F}
\end{aligned}
$$

where alpha $(\alpha)$ is calculated uptake efficiency of test chemical from diet, $\mathrm{C}_{0}$, fish is concentration in fish at the beginning of depuration derived from the regression line intercept, $\mathrm{K}_{\text {total }}$ is overall elimination rate constants, $\mathrm{I}$ is feeding rate, $C_{\text {diet }}$ is concentrations of test substance in the test diet, $\mathrm{t}$ is duration of uptake phase, BMF is biomagnification factor, $\mathrm{K}_{\text {elim }}$ is growth-corrected elimination rate constants, $\mathrm{BMF}_{\text {lipid }}$ is lipid- corrected $\mathrm{BMF}$ and $\mathrm{F}$ is lipid corrected factor: fish ${ }_{\text {lipid }} /$ diet $_{\text {lipid. }}$.

\section{Results and Discussion}

There was no mortality in any exposed or control fish. The overall growth rates constants (during entire study) of fish in the aqueous exposure test were $0.0186 \mathrm{~g} \mathrm{~d}^{-1}$ (high level), $0.0186 \mathrm{~g} \mathrm{~d}^{-1}$ (low level) and $0.0188 \mathrm{~g} \mathrm{~d}^{-1}$ (control). The overall growth rates constants in the dietary exposure test were $0.0278 \mathrm{~g} \mathrm{~d}^{-1}$ (high level), $0.0291 \mathrm{~g} \mathrm{~d}^{-1}$ (low level) and $0.0265 \mathrm{~g} \mathrm{~d}^{-1}$ (control). There were no significant differences between growth rates at either exposure level for both tests ( $t$ test, $p>0.05$ ). 
Table 3 Tissue concentrations and quantity of nitrofen (NIP) and hexachlorobenzene (HCB)

\begin{tabular}{|c|c|c|c|c|c|c|c|c|}
\hline \multirow[t]{3}{*}{ Part of fish } & \multicolumn{3}{|c|}{ Aqueous exposure test } & \multicolumn{5}{|c|}{ Dietary exposure test } \\
\hline & \multirow{2}{*}{$\begin{array}{l}\text { Wet } \\
\text { weight (g) }\end{array}$} & \multicolumn{2}{|l|}{ NIP } & \multirow{2}{*}{$\begin{array}{l}\text { Wet } \\
\text { weight }(\mathrm{g})\end{array}$} & \multicolumn{2}{|l|}{ NIP } & \multicolumn{2}{|l|}{ HCB } \\
\hline & & $\begin{array}{l}\text { Concentration } \\
\left(\mu \mathrm{g} \mathrm{g}^{-1}\right)\end{array}$ & $\begin{array}{l}\text { Quantity } \\
(\mu \mathrm{g})^{\mathrm{a}}\end{array}$ & & $\begin{array}{l}\text { Concentration } \\
\left(\mu \mathrm{g} \mathrm{g}^{-1}\right)\end{array}$ & $\begin{array}{l}\text { Quantity } \\
(\mu \mathrm{g})^{\mathrm{a}}\end{array}$ & $\begin{array}{l}\text { Concentration } \\
\left(\mu \mathrm{g} \mathrm{g}^{-1}\right)\end{array}$ & $\begin{array}{l}\text { Quantity } \\
(\mu \mathrm{g})^{\mathrm{a}}\end{array}$ \\
\hline Dermis & 6.31 & 1.59 & $10.0(7)$ & 2.36 & 3.44 & $8.12(9)$ & 9.11 & $21.5(10)$ \\
\hline Head & 16.7 & 3.74 & $62.5(46)$ & 6.14 & 5.80 & $35.6(41)$ & 13.1 & $80.4(36)$ \\
\hline Digestive tract & 2.39 & 2.03 & $4.85(4)$ & 1.05 & 3.70 & $3.89(5)$ & 10.0 & $10.5(5)$ \\
\hline Hepatopancreas & 0.881 & 2.99 & $2.63(2)$ & 0.362 & 5.91 & $2.14(2)$ & 22.0 & $7.96(4)$ \\
\hline Viscera & 2.34 & 7.83 & $18.3(14)$ & 0.780 & 17.8 & $13.9(16)$ & 53.4 & $41.7(19)$ \\
\hline Muscle & 25.1 & 1.45 & $36.4(27)$ & 8.85 & 2.55 & $22.6(26)$ & 7.08 & $62.7(28)$ \\
\hline Total & 53.7 & 2.51 & $135(100)$ & 19.5 & 4.41 & $86.5(100)$ & 11.5 & $225(100)$ \\
\hline
\end{tabular}

${ }^{a}$ Value in parentheses shows percentage distribution of test substances on a whole-body basis

The measured concentrations of NIP in the water of the aqueous exposure tests were $4.68 \pm 0.32 \mu \mathrm{g} \mathrm{L}^{-1}$ (high level) and $0.466 \pm 0.025 \mu \mathrm{g} \mathrm{L}^{-1}$ (low level). The $\mathrm{BCF}_{\mathrm{k}}$ was 5,100 (high level) and 5,100 (low level), $\mathrm{BCF}_{\mathrm{ss}}$ was 5,400 (high level) and 4,700 (low level). The 5\%-lipid normalised $\mathrm{BCF}_{\mathrm{k}}\left(\mathrm{BCF}_{\mathrm{k}}\right.$, lipid $)$ was 5,200 (high level) and 6,100 (low level). The concentration of NIP in tissues of fish $\left(\mu \mathrm{g} g\right.$ wet $\left.\mathrm{wt}^{-1}\right)$ from the aqueous exposure test was highest in viscera, followed by head, hepatopancreas, digestive tract and dermis, with the lowest concentration in muscle (Table 3).

Concentrations of NIP in the test diet $\left(\mathrm{C}_{\text {diet }}\right)$ were $1,000 \pm 21 \mathrm{~g} \mathrm{~g}^{-1}$ (high level) and $104 \pm 6 \mu \mathrm{g} \mathrm{g}^{-1}$ (low level). The concentrations of HCB in the test diet were $96.7 \pm 3.2 \mu \mathrm{g} \mathrm{g}^{-1}$ (high level) and 93.6 $\pm 2.4 \mu \mathrm{g} \mathrm{g}^{-1}$ (low level). The $\mathrm{BMF}_{\text {lipid }}$ was 0.137 (high level) and 0.137 (low level). The concentration of NIP in tissues of fish from the dietary exposure test was highest in viscera, followed by hepatopancreas, head, digestive tract and dermis, with the lowest concentration in muscle (Table 3 ).

Test fish in the dietary exposure test were exposed to a complex diet containing both NIP and HCB, whereas, fish in the aqueous exposure test were only exposed to NIP. The use of a reference substance provides a check on the assimilation efficiency resulting from the method used to spike the diet, but the test substance and reference substance should not interact with each another (Anonymous 2004b). In this test, we observed high assimilation efficiencies $(\alpha)$ for HCB (0.717-0.733), which indicates a sufficient bioavailability of the spiked diet. HCB is generally not metabolized by fish and so should not affect the metabolic capacity of the fish. In fact, BMF parameters for HCB did not change under the different dosing concentrations of NIP in this test. Therefore, we conclude that the use of HCB did not affect the accumulation potential or the comparison of NIP distribution in tissue in this study.
Fig. 1 Distribution of lipids and test substances in fish tissues on a whole-body basis. Value in column shows percentage distribution of test substances on a whole-body basis




Growth-corrected elimination half lives $\left(t_{1 / 2}\right)$ were similar values between both exposure tests; $2.1-3.0$ days via aqueous exposure and 2.7-2.9 days via dietary exposure. To compare the distributions of NIP and lipid content in tissues, we measured both the lipid and NIP content in the same group of fish. The comparison of percentage distributions on a whole-body basis is shown in Fig. 1. Despite the difference in uptake routes, the percentage of whole-body NIP found in muscle was almost the same for the two routes $-27 \%$ via aqueous exposure and $26 \%$ via dietary exposure. Furthermore, the distribution patterns of NIP and the lipid content of tissues on a percentage basis were similar - highest in the head, followed by muscle, viscera, dermis, digestive tract and hepatopancreas. There was no specific accumulation in the dermis or digestive tract, which were in direct contact with the NIP. We conclude that there is a strong relationship between tissue distribution of NIP and lipid content, independent of the uptake route. Our results provide laboratory data useful for environmental and human risk assessments.

Acknowledgments The dietary exposure test was commissioned in part by the Ministry of Economy, Trade and Industry of Japan.

Open Access This article is distributed under the terms of the Creative Commons Attribution Noncommercial License which permits any noncommercial use, distribution, and reproduction in any medium, provided the original author(s) and source are credited.

\section{References}

Anonymous (2004a) Fish, dietary bioaccumulation study: basic protocol, 20 Jan 2004. Document 071121_Chapter_R.11_
Final.doc submitted to the technical committee for new and existing substances working group (TC-NES) by the persistent bio-accumulative and toxic (PBT) working group

Anonymous (2004b) Fish, dietary bioaccumulation study: background document to the fish dietary study protocol, 20 Jan 2004. Document 071121_Chapter_R.11_Final.doc submitted to TCNES by the PBT working group

Arnot JA, Gobas FAPC (2006) A review of bioconcentration factor (BCF) and bioaccumulation factor (BAF) assessments for organic chemicals in fish. Environ Rev 14(4):257-297

Bertelsen SL, Hoffman AD, Gallinat CA, Elonen CM, Nichols JW (1998) Evaluation of $\log \mathrm{K}_{\mathrm{ow}}$ and tissue lipid content as predictors of chemical partitioning to fish tissues. Environ Toxicol Chem 17:1447-1455

Bligh EG, Dyer WJ (1959) A rapid method of total lipid extraction and purification. Can J Biochem Physiol 37:911-917

Gobas FAPC, Wilcockson JB, Russell RW, Haffner GD (1999) Mechanism of biomagnifications in fish under laboratory and field conditions. Environ Sci Technol 33:133-141

Harada M (1995) Minamata disease: methylmercury poisoning in Japan caused by environmental pollution. Crit Rev Toxicol 25(1):1-24

Ministry of Economy, Trade and Industry [METI] (2003) Concentration tests of chemical substances in fish. Available via http://www.meti.go.jp/english/information/data/TESTfish.html. Accessed 8 Dec 2010

Newman MC (2009) Fundamentals of ecotoxicology, 3rd edn. CRC Press, FL

Organization for Economic Co-operation and Development [OECD] (1996) OECD Guidelines for testing of chemicals, guideline 305. Bioconcentration: flow-through fish test. Organization for Economic Co-operation and Development, Paris

Tietge JE, Johnson RD, Jensen KM, Cook PM, Elonen GE, Fernandez JD, Holcombe GW, Lothenbach DB, Nichols JW (1998) Reproductive toxicity and disposition of 2,3,7, 8-tetrachlorodibenzo-p-dioxin in adult brook trout (S. fontinalis) following a dietary exposure. Environ Toxicol Chem 17:2395-2407 